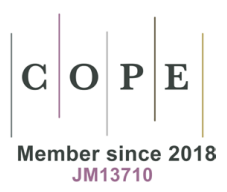

EUROPEAN SPATIAL RESEARCH AND POLICY

Volume 27 2020

Number 1

http://dx.doi.org/10.18778/1231-1952.27.1.02

\author{
Ilaria MARIOTTI* iD, Mina AKHAVAN*
}

\title{
EXPLORING PROXIMITIES IN COWORKING SPACES: EVIDENCE FROM ITALY
}

\begin{abstract}
Since the mid-2000s, the rising phenomenon of coworking spaces (CSs) has provided a flexible and mainly affordable solution for freelancers, entrepreneurs, small firms and start-ups, which may had experienced the issues of isolation when working from home, to work in a shared workplace, interact, socialize and share knowledge. This article explores the phenomenon of CSs within the theoretical framework of proximity measures a là Boschma (2005) - cognitive, organisational, social and institutional - that underpin the aspects of innovation, interaction and knowledge exchange. Though some studies on CSs have indirectly studied the different aspects of proximity, only a few of them focused on the importance of proximity measures at the workspace. With the aim to fill the gap in the literature, an empirical study was applied to Italy with 549 active CSs in 2018. The data was collected through an on-line questionnaire, addressed to a sample of 326 coworkers, focusing mainly on the set of questions devoted to understanding whether coworkers have exploited the proximity typologies in their CSs, have experienced increases in their revenues and well-being. The results are critically discussed, and some insights on policy implications are proposed.
\end{abstract}

Key words: coworking space, coworker, proximity measures, Italy.

\section{INTRODUCTION}

Within the last decade, the nature of work has changed significantly. Working has become less dependent on distance, time or space (Gaspar and Glaeser, 1998; Joroff, 2002). Despite that, due to the emergence of the knowledge economy (Dolfsma and Soete, 2006; Neef, 1998; Cooke, 2002), technological developments and the digital economy, and also because of the rising number of self-employment, freelance and independent workers, more flexible forms of working are becoming prominent,

\footnotetext{
* Ilaria MARIOTTI, Mina AKHAVAN, Politecnico di Milano, Department of Architecture and Urban Studies (DAStU), e-mails: ilaria.mariotti@polimi.it, mina.akhavan@polimi.it, ORCID: https://orcid.org/0000-0001-8034-6914
} 
as opposed to the traditional work (full-time employment) (Howell and Bingham, 2019). Thanks to the diffusion of the Information and Communication Technology (ICT) people can work remotely: working from home, or using public spaces, such as libraries, cafés/ bars, hotel and airport lounges, which are typically not planned to host productive activities, yet are increasingly being occupied as spaces for work (Di Marino and Lapintie, 2017) - also known as 'third places' (Oldenburg, 1989) for work ${ }^{1}$. The borders between private homes, productive spaces and socialising site are thus becoming less evident (Moriset and Malecki, 2009; Fonner and Stache, 2012; Gold and Mustafa, 2013). However, teleworking in such an informal working environment entails a lack of face-to-face interaction. In other words, early stage entrepreneurs, freelance, self-employed and independent knowledge workers need social and professional interactions in order to overcome the risk of isolation and loneliness - typical of working from home - and also to increase meeting and networking opportunities (Johns and Gratton, 2013; Moriset, 2014; Mariotti et al., 2017). Proximity studies have underlined the impact of geographical proximity, as well as agglomeration economies, on interactive learning and innovation (Boschma, 2005). Furthermore, the importance of geographical proximity should always be examined in relation to other proximity dimensions (see Section 2).

Within this context, since the mid-2000s, a relatively new and promising form of a workplace, known as a coworking space (hereinafter CS), has emerged that is becoming increasingly accepted by diverse groups of workers - from freelance, self-employed individuals and entrepreneurs to dependant contractors, with various professional profiles and competencies, ranging from the creative industry - e.g. architects, designers, journalises, etc. - to engineering and digital sectors, namely IT, software developers, consultants, etc. (Gandini, 2015; Spinuzzi, 2012).

Although coworking is becoming more and more popular worldwide, the phenomenon of CSs is still relatively new, and yet to be studied both theoretically and empirically. Within this framework, this paper aims to fill that gap in the literature as it has not yet tackled the role of the proximity measures a là Boschma (2005) - cognitive, organisational, social and institutional - in the development of community within a coworking space, as well as in fostering innovation, interaction, and knowledge exchange, but also economic performance and well-being. To reach this goal we shall analyse and discuss the results of a survey addressed to a sample of 326 coworkers.

The remainder of this paper is structured as follows. The next section briefly reviews the literature on CSs, as well as the proximity studies in the economic literature, in order to position the current paper within a theoretical sphere. The

\footnotetext{
${ }^{1}$ Interestingly, Morrison (2018) has reconceptualised in the Fourth Place the combination of the First, Second and Third Place. The Fourth Place aims to foster networking, promote mingling (combination of the First and Third places), and to favour collaboration, face-to-face interactions, and the exchange of tacit knowledge.
} 
third section is dedicated to the empirical study on Italy; the methodology and the mode of data collection are described in length. In Section 4 a discussion of the descriptive statistics is presented. The final section summarises the main findings and outlines some policy implications that brings the paper to a close.

\section{THE THEORETICAL FRAMEWORK: COWORKING SPACES AND THE PROXIMITY DIMENSIONS}

\subsection{The phenomenon of coworking spaces}

CSs are membership-based workplaces that ensure a flexible workplace: with a monthly/daily rent the individual gains the right to enter and work in the space, as well as a membership in social and professional community. Each 'coworking-user' or coworker (hereinafter CW) works separately - being assigned a desk/ office space - in a physical space which is shared with others (Raffaele and Connell, 2016). The CS model has gained legitimacy among different group of professionals not only for its provision of office space and its cost-effectiveness, but also for its capacity to establish a community (Akhavan and Mariotti, 2018) and a quality of working behaviour of 'working-alone-together' (Spinuzzi, 2012). According to Kwiatkowski and Buczynski (2011, p. 19), CWs share five main values: collaboration (the willingness to cooperate with others to create shared values), community (intangible benefits, shared purpose), sustainability (do good to do well and offset the environmental footprint of the space), openness (free sharing of ideas, information and people), and accessibility (financially and physically accessible, diversity). Therefore, CSs are regarded as a profitable business model that may intensify private and business relationships, along with a high level of autonomy that serves experimentation and creativity (Bouncken and Reuschl, 2018).

Moreover, Merkel $(2015$, p. 122) has stated that "as flexibly rentable, cost-effective and community-oriented workplaces, coworking spaces facilitate encounters, interaction and a fruitful exchange between diverse work, practice, and epistemic communities and cultures". For Davies and Tollervey (2013), the CS model may facilitate the creation of an economy than supports community and innovation. In such environment, each $\mathrm{CW}$ can, therefore, learn from others through sharing spaces, interaction and being part of the social/ professional activities offered by an organisation. Some scholars have classified coworkers based on what they may earn from CSs (Bilandzic and Foth, 2013):

- Utilizers, use CSs for their demand to technological infrastructure;

- Learners, make use of CSs in order to gain and exchange knowledge, attending events, etc.;

- Socializers, seek recognition and acknowledgment in CSs. 
Though their economic significance remains uncertain, the importance of emerging new workplaces, and more specifically the CS, in the era of digital economy - with a growth in entrepreneurship, freelance and teleworkers - is characterised by their dramatic global spread, specially since the mid-2000s. This statement is also evident in the numbers collected by Deskmag ${ }^{2}$ and reported in their 2019 Global Coworking Survey: the coworking movement has roughly doubled in size each year since 2006 and by the end of 2019 almost 2.2 million people are expected to work in over 22,000 coworking spaces worldwide.

Table 1 outlines some relevant publications from various disciplines on CSs - from 2012 to the very recent (2019) - that define CSs. Although the literature on the emerging workplaces in general, and specifically on CSs, is rather scarce, during the recent years this topic has been drawing a growing attention.

Table 1. Definition of CSs based on different disciplines

\begin{tabular}{|l|l|l|}
\hline \multicolumn{1}{|c|}{ Contribution } & \multicolumn{1}{|c|}{ Discipline } & \multicolumn{1}{c|}{ Definition of CS } \\
\hline Spinuzzi (2012) & Sociology & $\begin{array}{l}\text { CSs are open-plan office environments in which people } \\
\text { work alongside other unaffiliated professionals for a fee }\end{array}$ \\
\hline Capdevila (2013) & $\begin{array}{l}\text { Business/ } \\
\text { Management }\end{array}$ & $\begin{array}{l}\text { CSs are defined as localised spaces where independent } \\
\text { professionals work sharing resources and their knowledge } \\
\text { with the rest of the community }\end{array}$ \\
\hline $\begin{array}{l}\text { Bilandzic and Foth } \\
\text { (2013) }\end{array}$ & Technology & $\begin{array}{l}\text { CSs provide ensure a flexible and autonomous use of } \\
\text { office and social space that eases the direct interaction } \\
\text { among the users for social, learning and business-related } \\
\text { interests }\end{array}$ \\
\hline Moriset (2014) & Geography & $\begin{array}{l}\text { CSs as potential "serendipity accelerators" ...beyond the } \\
\text { room layout, coworking is first an atmosphere, a spirit, } \\
\text { and a lifestyle }\end{array}$ \\
\hline $\begin{array}{l}\text { Avdikos and } \\
\text { Kalogeresis (2017) }\end{array}$ & Economy & $\begin{array}{l}\text { It helps freelance designers become more embedded in } \\
\text { business networks (in terms of collaborations), both local and } \\
\text { foreign, compared with working in isolation, as lone eagles }\end{array}$ \\
\hline $\begin{array}{l}\text { Robelski } \text { et al. } \\
\text { (2019) }\end{array}$ & $\begin{array}{l}\text { Psychology/ } \\
\text { Health care }\end{array}$ & $\begin{array}{l}\text { As a telework arrangement, coworking spaces are } \\
\text { becoming an increasingly established workplace among } \\
\text { the self-employed and freelancers working in the creative } \\
\text { line of business, as opposed to home office that is mainly } \\
\text { used by employed workers }\end{array}$ \\
\hline
\end{tabular}

Source: updated from Akhavan and Mariotti (2018, p. 87).

For Moriset (2014), CSs are 'accelerators of serendipity': serendipity of production for creative people and entrepreneurs who are in search for working envi-

${ }^{2}$ See www.deskmag.com. 
ronments to enhance the chances of meeting others and collaboration. Others have discussed the 'sense of community' offered by CSs to overcome the issue of social isolation, which may affect independent workers and teleworkers (Garrett et al., 2017; Blagoev et al., 2019; Spinuzzi et al., 2019). Therefore, individuals can satisfy their needs for social interactions while maintaining their desired autonomy and independency at work. A recent study by Akhavan and Mariotti (2018) on a sample of $236 \mathrm{CW}$ in Italy (July 2017) provided insights on how coworkers experienced a sense of community inside their working spaces and outside in the urban context: the majority of CWs, who responded to the questionnaire, reported that they had experienced social proximity, and had also perceived a positive impact of the CS on their urban environment, the neighbourhood in this case.

\subsection{Proximity dimensions}

The importance of proximity has been addressed in literature that spans across different discipline boundaries: from urban and regional economics, economic geography to innovation economics and evolutionary economic geography (Salvador et al., 2013). In the economic geography literature, proximity is considered fundamental as it "underpins the joint production, circulation and sharing of knowledge" (Gertler, 2008, p. 203). At the beginning of the 1900s, economists recognised that spatial and social proximities play a key role in corporate growth and competitiveness (Weber, 1909/1929). More specifically, geographical and social proximities have been addressed as two genetic conditions necessary, though not enough, for an area to be an industrial district (Capello, 2007). The first attempt at a formal classification of the reasons for companies agglomerating in an industrial district was made by Marshall (1925) and subsequently by Becattini (1990). The Marshallian industrial district and its Italian variant version stressed the role of space as the generator of locational advantages: lower production and transaction costs, and a more efficient use of resources, which enable firms to achieve higher levels of productivity and profit (Capello, 2007, p. 193). Additionally, in the 1980s, the work developed by the GREMI group (Groupe de Recherche Européen sur les Milieux Innovateurs) stressed the role played by innovation in enhancing economic development, and concluded that the factors related to 'relational proximity' (social interactions, interpersonal synergies, and collective action among actors) enhance innovative capacity (see, e.g. Aydalot, 1986). According to this theory, economic and social relations among local actors influence the innovative capacity and economic success of specific local areas termed 'milieu innovateurs' (Capello, 2007). Moreover, Torre and Gilly (2000) and Torre (2010) stressed the importance of organised proximity ${ }^{3}$, that is

\footnotetext{
${ }^{3}$ For a review of the role of organizational structure, see Allen et al. (2008).
} 
not geographic but relational, and expressed the way in which two actors could be close regardless of the kind of geographical relationship (i.e. level of interaction, sharing knowledge, social relation, etc.).

Although a large body of literature confirms that agglomeration and geographical proximity positively affect the formation of ties in knowledge networks (Hardeman et al., 2012; Balland et al., 2015), there are other forms of proximity crucial to innovation and knowledge exchange (Boschma, 2005). In 2005, Ron Boschma recalled the proximity measures and underlined that geographical proximity could not be assessed in isolation but should always be examined in relation to other proximity measures (cognitive, organisational, social and institutional) that may provide solutions to the problem of coordination. Indeed, due to advanced information and communication technologies, networks through which learning takes place are not necessarily spatially delimited. The proximity measures a là Boschma (2005) are the following: (i) Cognitive: people sharing the same knowledge base and expertise may learn from each other, facilitating effective communication; (ii) Organisational: such as networks, which are mechanisms that not only coordinate transactions but also enable the transfer and exchange of information and knowledge beneficial for learning and innovation; (iii) Social: socially embedded relations between actors at the micro-level (based on friendship, kinship and past experience) that may stimulate interactive learning due to trust and commitment (elements of social capital e.g. trust); (iv) Institutional: common habits, routines, established practices, rules, or laws that regulate the relations and interactions between individuals, which may reduce uncertainty and bases for economic coordination and interactive learning; (v) Geographical: the spatial or physical distance - short distances bring people together, favouring contacts and facilitating the exchange of tacit knowledge (see also Akhavan and Mariotti, 2018).

Some studies have confirmed that the different proximity dimensions should not be considered separately and it is crucial to study their interaction. In this regard, Cohen and Prusak (2001) discussed the face-to-face contact that enhances other forms of proximity essential for knowledge exchange within organizations. Balland et al. (2015) have studied the joint and co-evolutionary dynamics between knowledge networking and proximity. They argued that the processes of learning, decoupling, institutionalisation, integration and agglomeration could affect the five proximity dimensions. Based on other empirical studies, geographical, organisational and institutional proximity measures favour collaborations (Balland, 2012). Others have found that geographical proximity positively affects tie formation in knowledge networks (Hardeman et al., 2012; Balland et al., 2015).

The proximity literature is generally based on the level of companies. Although a few studies on CSs have indirectly addressed the different aspects of proximity, only a few researches have directly focused on the importance of proximity dimensions at the workplace level. The empirical work by Parrino (2015) - on CSs in Milan and Barcelona - has shed light on the theoretical framework of 
proximity in CSs and examined specifically the role of proximity in facilitating interactions and the transmission of knowledge among the workers in CSs, and the relational potential of geographic proximity of CWs. This analysis is based on the qualitative study of two maximum-variation case studies of CSs: the first where CWs share only a physical space, few are the manifestations of sociality, and the transmission of knowledge among CWs proved to be scarce and episodic; the second where CWs exploit the organisational platform managed by the CS, experience knowledge flows with other CWs, and interact frequently.

\section{AN EMPIRICAL STUDY ON ITALY}

\subsection{Data collection and methodology}

The study presented in this paper is based on the data collected through the research project entitled "New working spaces. Promises of innovations, effects on the economic and urban context" exploring new workplaces, coworking spaces and makers spaces, in Italy - FARB Project, funded by the Department of Architecture and Urban Studies (DAStU), Politecnico di Milano. The data was collected from two main sources:

- an original georeferenced database on CSs in Italy was developed; it contains all the necessary details, such as size, number of desks, facilities offered, etc. The data was collected mainly from the official websites of CSs and through contacting some of the spaces for the missing information;

- an online survey (questionnaire), which was sent to CS managers to be distributed among CWs.

As of January 2018, Italy hosted 549 CSs: about 50\% were located in Italian metropolitan cities, with Milan (112), Rome (50), Turin (23), and Florence (17) hosting about half of them (Fig. 1). As expected, Mariotti et al. (2017) have found that in the case of Milan, CSs were mainly agglomerated in urban centres where there was a concentration of urban amenities. 


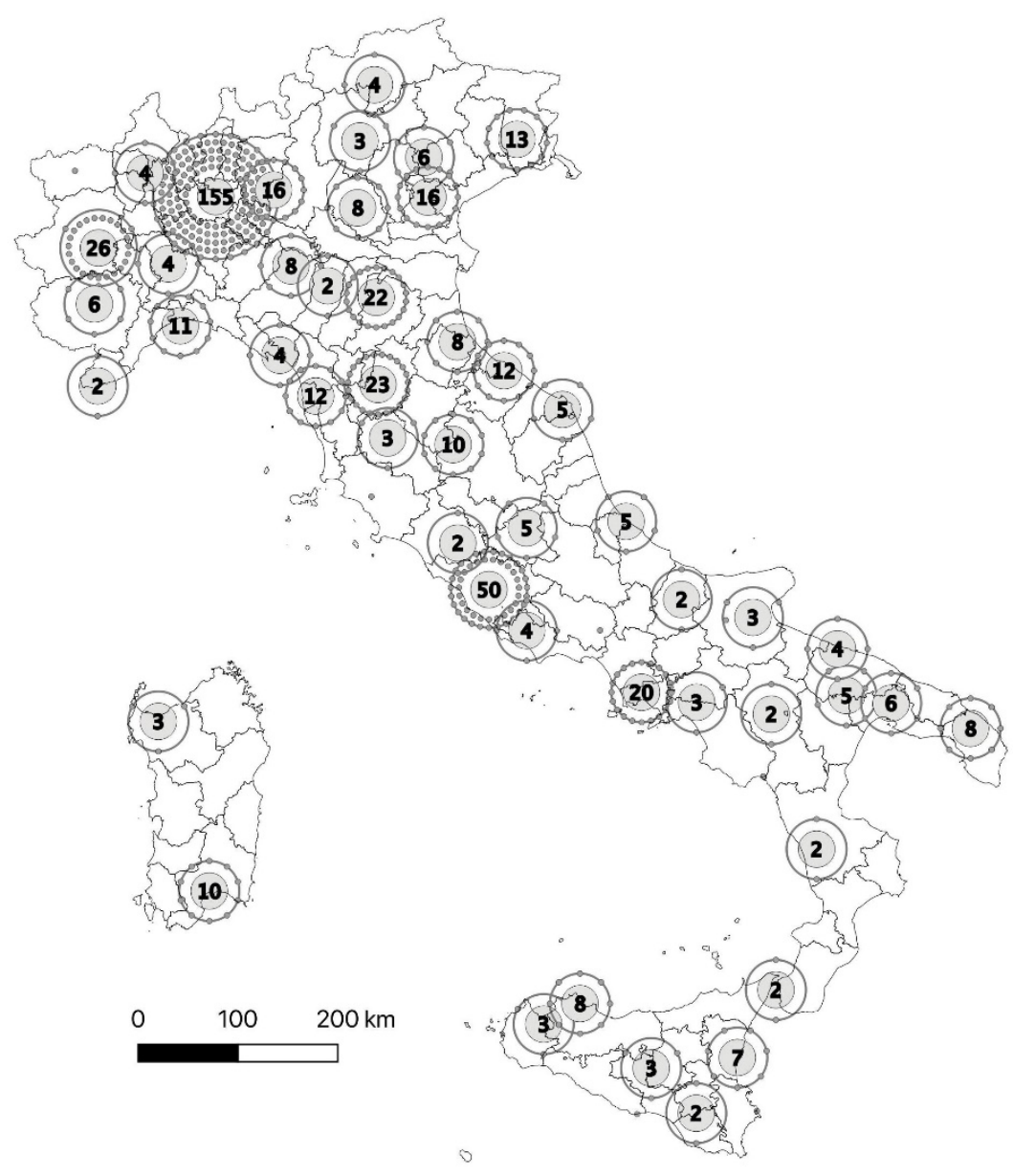

Fig. 1. The location of CSs in Italy as of January 2018

Source: own work.

The on-line questionnaire was composed of 55 questions, structured in 7 sections:

1. Socio-demographics (gender, years, age, education, etc.), employment position and sector;

2. Motivation for selecting the coworking space (location factors);

3. Perceived and expected advantages and dis-advantages to work in a CS;

4. Proximity typologies (social, institutional, cognitive, organizational);

5. Level of satisfaction in working in the CS;

6. Willingness to work in a CS in the next 3-years;

7. Impact on the neighbourhood. 
In order to control the proximity dimensions a là Boschma (2005), we asked the following questions:

- Social proximity

1. Have you made new friends?

2. Are your relationships with most coworkers based on trust?

- Institutional proximity

1. Do you find that there is an affinity in terms of principles between you and a significant number of coworkers? (political ideas)

2. Do you find that there is an affinity in terms of principles between you and a significant number of coworkers? (lifestyle)

- Cognitive proximity

1. Do the coworkers with whom you share space have on average your level of knowledge?

2. Do the coworkers with whom you share space have on average your level of experience?

- Organisational proximity

o The choice to work in a shared space is related to its useful service/ to have access to training opportunities/ To have access to new information channels/ to have access to spaces such as meeting room, kitchen, etc./ to have access to services such as secretariat, administration, etc.

Geographical proximity was defined as the co-location of CWs which existed in CSs. Social proximity concerns the elements of social capital (e.g. trust) that enhance socially embedded relations between agents, in this case CWs, at the micro-level (Boschma, 2005). Institutional proximity is proxied by the affinity among the CWs regarding their political attitudes and lifestyle, which facilitates the development of a "sense of community". Sharing the same level of knowledge and experience concerns cognitive proximity, which stimulates collaboration and fosters new business opportunities. Finally, organisational proximity is proxied by the services and facilities offered by the organisational platform of a CS, and most of the times by the coworking manager themselves, which can enhance knowledge flows among workers heterogeneous in terms of their occupation, business sector, organisational status, affiliation and personal and organisational motivations (Parrino, 2005) ${ }^{4}$.

\section{EMPIRICAL ANALYSIS AND FINDINGS}

By January 2018, 326 CWs, from 138 CSs (about 25\% of the total), answered the questionnaire. They were located in 83 cities homogenously distributed in the four macro areas (the north-west, the north-east, the centre, the south and islands).

\footnotetext{
${ }^{4}$ All the CSs studied have developed an organisational platform.
} 
There is a concentration in the Italian Metropolitan areas 5 (34\%), with Milan registering $60 \mathrm{CWs}$. $44 \%$ of the respondents were female and $56 \%$ male; $52 \%$ were aged 36-50, followed by CWs aged between 25 and $35(38 \%)$, over $51(9 \%)$, and those aged 19-24 (1\%). They were mainly freelancers (48\%), employees $(29 \%)$, managers (19\%) and other (11\% - apprentices, stagers, students). About $37 \%$ had spent at least 6 months abroad, for the purpose of education or work. The CWs' sectors of work mainly belonged to the creative industry ( $65 \%)$, followed by management consultancy, training, and other sectors.

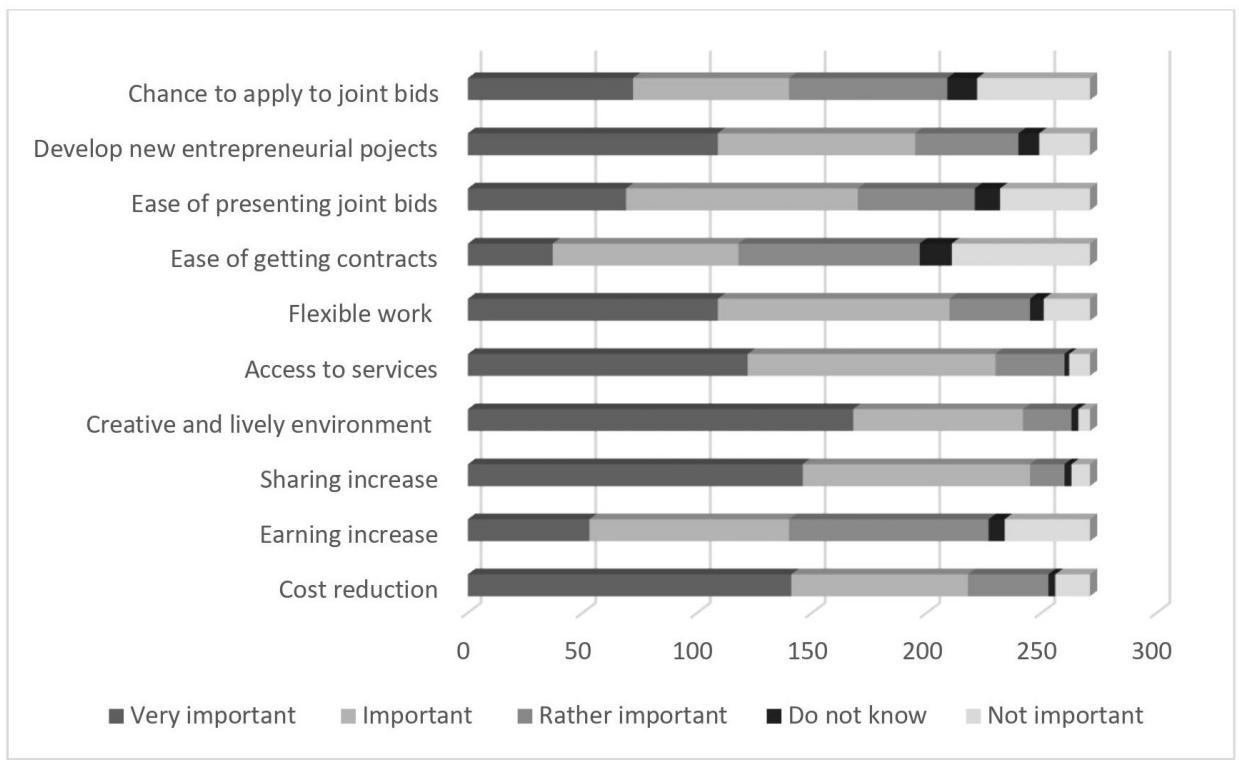

Fig. 2. Motivation for selecting the coworking space (pull factors)

Source: own work.

The CWs underlined that the main ("very important") motivation supporting the selection of a CS was related to cost reduction (Fig. 2). Indeed, during the economic downturn, CSs represent a valid and cheaper alternative to traditional offices. Other pull factors applied to the opportunity: (i) to work in a lively and creative environment, that well fits the CWs that were mainly specialised in the creative industry; (ii) to increase knowledge sharing; (iii) to access shared services

\footnotetext{
${ }^{5}$ In Italian known as Città metropolitana, Metropolitan cities are administrative divisions, which are comparable to the provincial scale, which includes a large core city and the smaller surrounding towns that are closely related to, economically and for provision of public facilities. They are 14 in total: Roma, Torino, Milano, Venezia, Genova, Bologna, Firenze, Bari, Napoli, Reggio Calabria, Catania, Messina, Palermo, Cagliari.
} 
and instruments (i.e. IT, secretary, common rooms, meeting rooms, etc.); (iv) to access a flexible labour organisation; (v) to develop new entrepreneurial projects; (vi) to apply for joint bids and ease of presenting joint bids; (vii) ease of getting contracts; and (viii) to increase earnings.

These answers stressed the importance that respondents allocated to the main patterns of the coworking: cost reduction and the lively and creative environment, characterised by the sharing of services, spaces and knowledge, which could increase new business opportunities. These answers underlined the role of organisational proximity that CWs experienced in a CSs (i.e. services, facilities, training courses, etc.), which enhanced knowledge sharing and business opportunities growth.

Table 2 . The proximity measures as declared by coworkers (percentage)

\begin{tabular}{|l|c|c|c|c|}
\hline \multicolumn{1}{|c|}{ Proximity typologies } & Yes & No & Do not know & Total \\
\hline Social proximity 1 & 77.6 & 19.9 & 2.5 & 100.0 \\
\hline Social proximity 2 & 73.7 & 19.6 & 6.7 & 100.0 \\
\hline Institutional proximity 1 & 54.9 & 23.9 & 21.2 & 100.0 \\
\hline Institutional proximity 2 & 73.6 & 14.1 & 12.3 & 100.0 \\
\hline Cognitive proximity 1 & 61.4 & 19.6 & 19.0 & 100.0 \\
\hline Cognitive proximity 2 & 55.8 & 27.3 & 16.9 & 100.0 \\
\hline Organisational proximity & 86.0 & 11.3 & 2.7 & 100.0 \\
\hline
\end{tabular}

Source: own work.

The questions about the proximity typologies a là Boschma (2005) showed interesting results (Table 2). About $74 \%$ of the respondents had experienced a relationship based on trust (social proximity 2) with most of the CWs; about 78\% had established friendships with them (social proximity 1), and specifically $52 \%$ with more than one third of the coworkers. About 55\% share similar political attitudes (institutional proximity 1), and 73\% similar lifestyles (institutional proximity 2); as for cognitive proximity, about $61 \%$ stated to have had similar levels of knowledge (cognitive proximity 1 ) and about 56\% similar levels of experience (cognitive proximity 2). Finally, $86 \%$ made use of the service and facilities offered by the CS (organisational proximity), including training courses, designed to encourage synergies among CWs.

These results confirmed the key role of the sense of community, which is funded in social proximity (trust, new friendship and collaboration) and institutional proximity (sharing the same lifestyle, political ideas, etc.). As stated by Kim and Kaplan (2004), the members of a community share the feelings of collective identity and may exploit a 'community spirit' (Etzioni, 1994; Rovai, 2002) if they 
share the feelings of understanding and belonging. The sense of community is also related to the space, services and facilities supplied by the CS (organisational proximity) and can also be enhanced by cognitive proximity. As stated by Davies and Tollervey (2013), each coworker can learn from others through sharing spaces, interacting and being part of the activities offered by an organisation.

Additional questions have further stressed the importance of the layout of CSs, which fosters meeting opportunities. For instance, about $38 \%$ of the CWs (always or very often) discussed working issues during lunch time, mainly in the kitchen or other dedicated spaces of the workplace.

All the above-mentioned effects of the workplace on coworkers might impact their economic performance and well-being. $39 \%$ of the CWs and $29 \%$ of the firms experienced revenue increases since they had started working in the CS. Interestingly, about $73 \%$ of the respondents declared to have developed new products and services, of those 52\% have done it jointly with other CWs. Additionally, almost all CWs (97\%) confirmed they were satisfied with working in the current CS. It can, therefore, be stated that CWs have evaluated positively their CSs, indeed 57\% declared that they intended to work in the same CS in the next three years, $5 \%$ would move to another CS, $34 \%$ did not know and only $4 \%$ would not work in a CS anymore.

\section{CONCLUSIONS AND POLICY IMPLICATION}

The current survey among $326 \mathrm{CWs}$ in Italy highlighted some interesting points: although the main motivation to work in a CS was cost reduction, a key role was played by the lively and creative environment, characterised by the sharing of services, spaces and knowledge, which enhanced social proximity and organisational proximity, thus increasing new business opportunities. Additionally, the CWs shared cognitive and institutional proximities since they had similar levels of knowledge and professional experience, as well as similar lifestyle and political attitudes, respectively. The sharing of knowledge and collaboration between the CWs fostered the development of new, innovative products or projects. Further, more than one third of the $\mathrm{CW}$ had experienced an increase in their revenues and almost everyone confirmed they were satisfied with working in a coworking setting.

The study offers interesting insights for policy makers willing to foster entrepreneurship in an ageing society to sustain the level of skilled employment. Coworking could be regarded as an opportunity to revitalise city centres by making use of empty office spaces (Mariotti et al., 2017), and foster the development of peripheral areas (Mariotti and Di Matteo, 2020), an issue that attracts a significant attention among academicians and policy makers especially during the current pandemic caused by the massive spread of the new coronavirus SARS-CoV-2. 
Indeed, peripheral destinations in Italy, probably because of the natural isolation that their orography imposes, are those which have suffered less from the spread of the COVID-19, and probably these places will be the first to remove the 'social distancing' principle and restart a normal life at the end of the emergency, thus being considered 'safer places'.

Further research might focus on a comparative study inside coworking spaces in different countries to explore the role of cultural and context factors in shaping coworking spaces and, consequently, the interactions among coworkers ${ }^{6}$. The present analysis requires some caveats. First, an appropriate counterfactual analysis might better disentangle the differences and similarities (i.e. economic performance and wellbeing) of the workers of CSs and those working in traditional offices and/or at home. Besides, the analysis only explored those that in January 2018 were working in a CS, thus excluding the ones that moved out. The results of the descriptive statistics should be also corroborated by an econometric analysis. This will be the objective of a future paper.

\section{REFERENCES}

AKHAVAN, M. and MARIOTTI, I. (2018), 'The Effects of Coworking Spaces on Local Communities in the ItalianContext', Territorio 87, pp. 85-92. https://doi.org/10.3280/TR2018-087014

ALLEN, T.J., TOMLIN, B. and HAUPTMAN, O. (2008), 'Combining organisational and physical location to manage knowledge dissemination', International Journal of Technology Management, 44 (1/2). https://doi.org/10.1504/IJTM.2008.020706

AVDIKOS, V. and KALOGERESIS, A. (2017), 'Socio-economic profile and working conditions of freelancers in co-working spaces and work collectives: evidence from the design sector in Greece', Area, 49 (1), pp. 35-42. https://doi.org/10.1111/area.12279

AYDALOT, Ph. (1986), (ed.), Miliex innovateurs en Europe, Paris: GREMI.

BALLAND, P.A. (2012), 'Proximity and the evolution of collaboration networks: Evidence from research and development projects within the global navigation satellite system (GNSS) industry', Regional Studies, 46 (6), pp. 741-756. https://doi.org/10.1080/00343404.2010.529121

BALLAND, P.-A., BOSCHMA, R. and FRENKEN, K. (2015), 'Proximity and Innovation: From Statics to Dynamics', Regional Studies, 49 (6), pp. 907-920.

BECATTINI, G. (1990), 'The Marshallian industrial district as socio-economic notion', [in:] PYKE, F., BECATTINI, G., SENGENBERGER, W. (eds.), Industrial districts and inter-firm cooperation in Italy, Geneve: International institute for Labour Studies.

BILANDZIC, M. and FOTH, M. (2013), 'Libraries as coworking spaces: Understanding user motivations and perceived barriers to social learning', Library Hi Tech, 31 (2), pp. 254-273. https:// doi.org/10.1108/07378831311329040

\footnotetext{
${ }^{6}$ This is the object of the four years Cost Action - CA18214 project, entitled: "The geography of new working spaces and the impact on the periphery" (https://www.cost.eu/cost-action/the-geographyof-new-working-spaces-and-the-impact-on-the-periphery/), which involves 28 countries and started in 2019. The authors are members of the project.
} 
BLAGOEV, B., COSTAS, J. and KÄRREMAN, D. (2019), “"We are all herd animals»: Community and organizationality in coworking spaces’, Organization, 135050841882100. https://doi. org/10.1177/1350508418821008

BOSCHMA, R. (2005), 'Proximity and Innovation: A Critical Assessment', Regional Studies, 39 (1), pp. 61-74. https://doi.org/10.1080/0034340052000320887

BOUNCKEN, R.B. and REUSCHL, A.J. (2018), 'Coworking-spaces: how a phenomenon of the sharing economy builds a novel trend for the workplace and for entrepreneurship', Review of Managerial Science, 12 (1), pp. 317-334. https://doi.org/10.1007/s11846-016-0215-y

CAPDEVILA, I. (2013), Knowledge dynamics in localized communities: Coworking spaces as microclusters. Available at SSRN: https://ssrn.com/abstract=2414121 or http://dx.doi.org/10.2139/ ssrn.2414121 (2016/05/25)

CAPELLO, R. (2007), Regional Economics, Routledge, London and New York.

COHEN, D. and PRUSAK, L. (2001), In Good Company: How Social Capital Makes Organizations Work, Harvard Business School Publishing, Boston, MA. https://doi.org/10.1145/358974.358979

COOKE, P. (2002), Knowledge Economies: clusters, learning and cooperative advantage, London: Routledge. https://doi.org/10.4324/9780203445402

DAVIES, A. and TOLLERVEY, K. (2013), The Style of Coworking: Contemporary Shared Workspaces, Munich: Prestel Verlag.

Di MARINO, M. and LAPINTIE, K. (2017), 'Emerging Workplaces in Post-Functionalist Cities', Journal of Urban Technology, 24 (3), pp. 5-25. https://doi.org/10.1080/10630732.2017.1297520

DOLFSMA, W. and SOETE, L. (eds.) (2006), Understanding the Dynamics of a Knowledge Economy, Cheltenham: Edward Elgar. https://doi.org/10.4337/9781845429898

ETZIONI, A. (1994), The Spirit of Community: The reinvention of American society, New York: Simon \& Schuster.

FONNER, K.L. and STACHE L.C. (2012), 'All in a day's work, at home: teleworkers' management of micro role transitions and the work-home boundary', New Technology, Work and Employment, 27 (3), pp. 242-257. https://doi.org/10.1111/j.1468-005X.2012.00290.x

GANDINI, A. (2015), 'The rise of coworking spaces: A literature review', Ephemera: Theory and Politics in Organizations, 15 (1), pp. 193-205.

GARRETT, L.E., SPREITZER, G.M. and BACEVICE, P.A. (2017), 'Co-constructing a Sense of Community at Work: The Emergence of Community in Coworking Spaces', Organization Studies, 38 (6), pp. 821-842. https://doi.org/10.1177/0170840616685354

GASPAR, J. and GLAESER, E.L. (1998), 'Information technology and the future of cities', Journal of Urban Economics, 43 (1), pp. 136-156. https://doi.org/10.1006/juec.1996.2031

GERTLER, M.S. (2008), 'Buzz without being there? Communities of practice in context', [in:] AMIN, A. and ROBERTS, J., (eds.) Community, Economic Creativity, and Organization, pp. 203-226, Oxford University Press, Oxford and New York. https://doi.org/10.1093/acprof:oso/9780199545490.003.0009

GOLD, M. and MUSTAFA, M. (2013), “«Work always wins»: client colonisation, time management and the anxieties of connected freelancers', New Technology, Work and Employment, 28 (3), pp. 197-211. https://doi.org/10.1111/ntwe.12017

HARDEMAN, S., FRENKEN, K., NOMALER, Ö. and TERWAL, A. (2012), 'A proximity approach to territorial science systems', EUROLIO Conference on 'Geography of Innovation', 24-26 January 2012, Saint-Etienne, France.

HOWELL, T. and BINGHAM, C. (2019), Coworking spaces: working alone, together, Kenan Institute Working Paper. Retrieved from https://www.kenaninstitute.unc.edu/index.php/publication/ coworking-spaces-working-alone-together/

JOHNS, T. and GRATTON, L. (2013), 'The Third Wave of Virtual Work - Harvard Business Review’, Harvard Business Review, 5 (I), pp. 1-16. 
JOROFF, M.L. (2002), 'Workplace mind shifts', Journal of Corporate Real Estate, 4 (3), pp. 266274. https://doi.org/10.1108/14630010210811886

KIM, J. and KAPLAN, R. (2004), 'Physical and Psychological Factors in Sense of Community: New Urbanist Kentlands and Nearby Orchard Village', Environment and Behaviour, 36 (3), pp. 313-340. https://doi.org/10.1177/0013916503260236

KWIATKOWSKI, A. and BUCZYNSKI, B. (2011), Coworking: How freelancers escape the coffee shop office, Fort Collins, Colorado, US: Cohere Coworking.

MARIOTTI, I. and DI MATTEO, D. (2020), 'Coworking in emergenza Covid-19: quali effetti per le aree periferiche?’, EyesReg, 10 (2): http://www.eyesreg.it/2020/coworking-in-emergenza-covid-19-quali-effetti-per-le-aree-periferiche/

MARIOTTI, I., PACCHI, C. and Di VITA, S. (2017), 'Coworking Spaces in Milan: Location Patterns and Urban Effects', Journal of Urban Technology, 24 (3), pp. 47-66. https://doi.org/10.10 80/10630732.2017.1311556

MARSHALL, A. (1925), Principles of Economics, 8th edition, London: Macmillan.

MERKEL, J. (2015), 'Coworking in the city', Ephemera | theory \& politics in organisation, 15 (1), pp. 121-139.

MORISET, B. (2014), 'Building new places of the creative economy: The rise of coworking spaces', 2nd Geography of Innovation International Conference 2014 Utrecht University, Utrecht, 23-25 January 2014.

MORISET, B. and MALECKI, E.J. (2009), 'Organization versus space: The paradoxical geographies of the digital economy', Geography Compass, 3 (1), pp. 256-274. https://doi.org/10.1111/ j.1749-8198.2008.00203.x

MORRISON, A. (2018), 'A typology of places in the knowledge economy: Towards the fourth place', International symposium on new metropolitan perspectives, pp. 444-451. https://doi. org/10.1007/978-3-319-92099-3_50

NEEF, D. (ed.) (1998), The Knowledge Economy, Boston: Butterworth-Heinemann.

OLDENBURG, R. (1989), The Great Good Place: Cafes, Coffee Shops, Bookstores, Bars, Hair Salons, and Other Hangouts at the Heart of a Community, New York: Paragon House.

PARRINO, L. (2015), 'Coworking: assessing the role of proximity in knowledge exchange', Knowledge Management Research \& Practice, 13 (3), pp. 261-271. https://doi.org/10.1057/ kmrp.2013.47

RAFFAELE, C. and CONNELL, J. (2016), 'Telecommuting and Co-Working Communities: What Are the Implications for Individual and Organizational Flexibility?', [in:] SUSHIL, CONNELL, J. and BURGESS, J. (eds.), Flexible Work Organizations, pp. 21-35. https://doi. org/10.1007/978-81-322-2834-9_2

ROBELSKI, S., KELLER, H., HARTH, V. and MACHE, S. (2019), 'Coworking Spaces: The Better Home Office? A Psychosocial and Health-Related Perspective on an Emerging Work Environment', International Journal of Environmental Research and Public Health, 16 (13), 2379. https://doi.org/10.3390/ijerph16132379

ROVAI, A.P. (2002), 'Building Sense of Community at a Distance', International Review of Research in Open \& Distance Learning, 3 (1), pp. 1-16. https://doi.org/10.19173/irrodl. v3i1.79

SALVADOR, E., MARIOTTI, I. and CONICELLA, F. (2013), 'Science park or innovation cluster? Similarities and differences in physical and virtual firms' agglomeration phenomena', International Journal of Entrepreneurial Behaviour \& Research, 19 (6), pp. 656-674. https://doi. org/10.1108/IJEBR-10-2012-0108

SPINUZZI, C. (2012), 'Working Alone Together: Coworking as Emergent Collaborative Activity', Journal of Business and Technical Communication, 26 (4), pp. 399-441. https://doi. org/10.1177/1050651912444070 
SPINUZZI, C., BODROŽIĆ, Z., SCARATTI, G. and IVALDI, S. (2019), ‘"Coworking Is About Community»: But What Is "Community» in Coworking?', Journal of Business and Technical Communication, 33 (2), pp. 112-140. https://doi.org/10.1177/1050651918816357

TORRE, A. (2010), 'Jalons pour une analyse dynamique des proximités', Revue d'Économie Régionale \& Urbaine (3), pp. 409-438. https://doi.org/10.3917/reru.103.0409

TORRE, A. and GILLY, J.-P. (2000), 'On the Analytical Dimension of Proximity Dynamics', Regional Studies, 34 (2), pp. 169-180. https://doi.org/10.1080/00343400050006087

WEBER, A. (1909/1929), Theory of the Location of Industries, trans. by FRIEDRICH, C.J. Chicago: University of Chicago Press. 